\section{MICROSTRUCTURE AND MICROANALYSIS (SEM/EDX) DETERMINATION OF GLASSES FROM MALLORCA AND MENORCA CAVES (1)}

\author{
DETERMINACIONDE LAMICROESTRUCTURA \\ $Y$ MICROANALISIS (SEM/EDX) DE VIDRIOS \\ PROCEDENTES DE CUEVAS DE MALLORCA \\ $Y$ MENORCA
}

\section{JESUS MARIA RINCON (*)}

that these glasses are deficient in sodium and highly enriched in $\mathrm{Al}_{2} \mathrm{O}_{3}$ and $\mathrm{Fe}_{2} \mathrm{O}_{3}$, their composition being in the range: 0.5-1.5 $\mathrm{K}_{2} \mathrm{O}, 8-10 \mathrm{CaO}, 6-8 \mathrm{Al}_{2} \mathrm{O}_{3}, 6-8 \mathrm{Fe}_{2} \mathrm{O}_{3}, 74-76 \mathrm{SiO}_{2}$ (wt \%). Some of these glasses also contain high percentages of lead. Small quantities of $\mathrm{TiO}_{2}, \mathrm{CuO}$ and $\mathrm{SO}_{3}(0.5 \%)$ have also been detected. Surface decoration and blue colour are other features of these ancient glasses, the surface of which, depicted by SEM, is highly altered with flaked and corroded microstructures.

\section{RESUMEN}

En los últimos años la aplicación de los métodos físicoquímicos de caracterización de materiales modernos al estudio de materiales antiguos es un campo de investigación de creciente interés para los arqueólogos. Este nuevo campo de investigación en Ciencia de los Materiales se viene denominando con el nombre de Arqueometría. Por lo tanto, muchas cuestiones sobre el origen y manufactura de los vidrios antiguos pueden resolverse usando los mismos métodos de análisis y de caracterización microestructural que se aplican normalmente a vidrios especiales o avanzados.

La isla de Mallorca ha sido en el pasado un lugar de paso $y$ de encuentro de diferentes culturas. Se han encontrado vidrios transparentes, opalescentes y coloreados en diferentes 
investigaciones arqueológicas llevadas a cabo en esta isla del Mediterráneo.

Para conocer la composición y microestructura de algunos vidrios encontrados en cuevas de Mallorca y Menorca se ha realizado, pues, un estudio arqueométrico por las técnicas de: Difracción de rayos $X$ (DRX); microscopia electrónica de Transmisión (MET), microscopia electrónica de barrido $y$ microanálisis por dispersión de energías de rayos $X$ (MEB/EDX), análisis térmico diferencial (ATD) y microscopia de calefacción (HSM). Los resultados de MEB/EDX de microanálisis promedio muestran que estos vidrios son deficientes en sodio y altamente enriquecidos en $\mathrm{Al}_{2} \mathrm{O}_{3}$ y $\mathrm{Fe}_{2} \mathrm{O}_{3}$ estando su composición en el intervalo: $0,5-1,5 \mathrm{~K}_{2} \mathrm{O}, 8-10$ $\mathrm{CaO}, 6-8 \mathrm{Al}_{2} \mathrm{O}_{3}, 6-8 \mathrm{Fe}_{2} \mathrm{O}_{3}, 74-76 \mathrm{SiO}_{2}$ (\% peso). Algunos de estos vidrios también contienen un alto porcentaje de plomo. $\mathrm{Se}$ han detectado pequeñas cantidades de $\mathrm{TiO}_{2}, \mathrm{CuO}$ y $\mathrm{SO}_{3}$ $(<0,5 \%)$. La superficie decorada, el color azul y las otras características de estos vidrios que muestran su superficie altamente corroida por MEB han sido también analizados y discutidos.

Key words: Ancient glasses. Archaeometry. Mallorca island. Scanning electron microscopy. X-Ray microanalysis.

Palabras clave: Vidrios antiguos. Arqueometría. Mallorca. Microscopía electrónica. Microanálisis.

\section{INTRODUCTION}

The Balearic islands, located in the Mediterranean sea, have been influenced in the past by several cultures. They were places of passage and foci of important commercial activities. In the larger islands, Mallorca and Menorca, caves frequently are found containing burials rich in archaeological ceramics and glassy materials (Waldren, 1981; Amorós, 1974, Enseñat, 1981). Thus, the burial caves from Massana, Campanet, Mallorca (Frontan, 1991), and Cales Coves, Alaior, Menorca (Veny, 1982) are two good examples. They have produced ceramics and glass beads which give rise to several important questions about the cultural infuences that have affected the Balearic islands in the past.

\section{MATERIALS AND METHODS}

Several glassy beads from the above mentioned burial caves have been selected for an archaeometric study by scanning electron microscopy and X-ray microanalysis.

Massana cave, Mallorca (Frontan, 1991), is located southwest of the mountain named Puig de la Mola near the village of Campanet. The cave's deposit is $2 \mathrm{~m}$. thick and constituted by lime burials. Glass beads are located throughout the deposit both in earlier and later levels. Blue glass beads are located in the lower level which dates to the IVth century B.C. White and pyramidal glass beads and beads with dolphin shape are found in the upper levels and are dated approximately to the IInd century B.C. Plate I shows the glass beads which we have analyzed from the Massana cave. The two views separated by arrows are of a bead with inlaid grains.

Cales Coves, on the coast of Menorca, are caves with burials cut into the limestone. The glass beads are found throughout the burials and possibly belong to different necklaces. They are found with bracelets, iron knives, bronzes, and rings and date to the IIInd century B.C. Plate II shows the appearance of the small glass beads analyzed here. The two samples consist of the beads in the upper and lower rows.

They are either brown in colour with blue circles or, more frequently, they have a silver plate surface with a metallic aspect.

The four samples have been broken, their surfaces have been cleaned with ethyl alcohol and mounted with carbon glue in sample holders for scanning electron microscopy (SEM). Energy dispersive X-ray analyses (EDX) were performed in order to determinate the chemical composition of these ancient glass beads.

The SEM/EDX configuration used here has been a SEM/EDX digitalized microscope, Zeiss DSM-950, and a EDX Tracor Northem series Z-II spectrometer. For best comparison of chemical composition, average microanalysis results at lower magnifications have been carried out in exactly the same conditions for each specimen. Semiquantitative analysis were made by using the ZAF correction software from Tracor (Mc Carthy, 1979). 
Plate I. Glass beads from the Massana cave, Mallorca, here investigated.

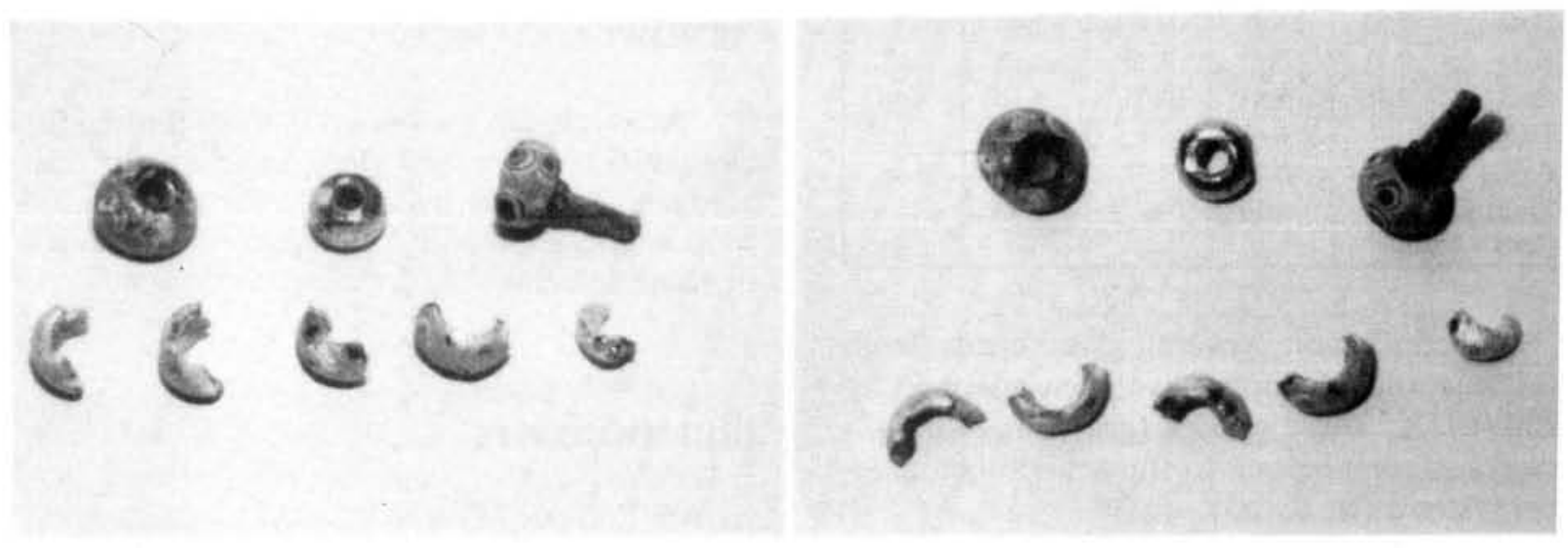

Plate II. Glass ancient beads from the Cales Coves, Menorca, here investigated.

\section{RESULTS AND DISCUSSION}

As is shown in Table I, the Massana glass bead including small quartz inlays in the surface is a high lead content glass, while the Massana grey glass bead is a lime-silica glass with high silica content. This grey glass has a high content of iron oxides ( $7.31 \mathrm{wt} \%$ expressed as $\mathrm{Fe}_{2} \mathrm{O}_{3}$ ). Therefore, although they are found in the same cave, these glass beads probably have different origins.

With respect to the Cales Coves glass beads there also exist differences. The silvered samples are soda-lime-silica glasses containing an important proportion of lead (7.48 wt \% $\mathrm{PbO})$ and iron (5.55 wt \% $\mathrm{Fe}_{2} \mathrm{O}_{3}$ ). Without considering this lead and iron content this glass could be similar to roman glasses from the Iberian Peninsula, like those previously studied by Rincón (1984). However, the blue glass bead is a high calcia-silica glass very close in composition to the Massana grey sample. Copper is present in a small proportion; the iron content is similar to the silvered sample; and the Massana grey sample has a low sodium content. This low sodium content $(\approx 0.09 \mathrm{wt} \%)$ could be related 
to leaching in the burial, as can be seen in the strongly etched surface by scanning electron microscopy (Plate III). Therefore, in spite of its different colour and size, the grey glass bead from Massana is very similar in composition to the blue glass bead from Cales Coves.

\section{TABLA 1}

EDX AVERAGE ANALYSIS ON ANCIENT CLASS BEADS FROM THE BALEAR ISLANDS

\begin{tabular}{|l|c|c|c|c|c|}
\hline \multicolumn{1}{|c|}{ sample } & Massana & same etched & Massana grey & Cales Coves & Cales Coves \\
& quartz inlays & & & silver & blue \\
\hline $\mathrm{Na}_{2} \mathrm{O}$ & 11.75 & 6.90 & - & 14,40 & 0.09 \\
$\mathrm{MgO} \mathrm{O}$ & 1.65 & 1.13 & - & - & 0.60 \\
$\mathrm{Al}_{2} \mathrm{O}_{3}$ & 0.89 & 3.05 & 6.16 & 3.59 & 7.81 \\
$\mathrm{SiO}_{2}$ & 41.71 & 28.15 & 76.13 & 56.43 & 73.86 \\
$\mathrm{SO}_{2}$ & - & - & - & - & 0.53 \\
$\mathrm{PbO}$ & 39.83 & 54.06 & - & 7.48 & - \\
$\mathrm{K}_{2} \mathrm{O}$ & 0.81 & 0.57 & 0.36 & 2.53 & 1.47 \\
$\mathrm{CaO}$ & 2.86 & 5.41 & 10.03 & 5.60 & 8.58 \\
$\mathrm{TiO}_{2}$ & - & - & - & 1.98 & 0.37 \\
$\mathrm{Fe}{ }_{2} \mathrm{O}_{3}$ & - & 0.22 & 7.31 & 5.55 & 6.48 \\
$\mathrm{ZnO}$ & 0.18 & 0.13 & - & 2.43 & - \\
$\mathrm{CuO}$ & - & - & - & - & 0.22 \\
\hline
\end{tabular}

In conclusion, several glass beads from Mallorca and Menorca have been analysed by SEM/EDX. These glasses (grey, blue and silvered surfaces) belong to the general composition systems (wt $\%>5$ ):

$$
\begin{gathered}
\mathrm{Na}_{2} \mathrm{O}-\mathrm{PbO}-\mathrm{SiO}_{2} \\
\mathrm{Na}_{2} \mathrm{O}-\mathrm{CaO}-\mathrm{Fe}_{2} \mathrm{O}_{3}-\mathrm{PbO}-\mathrm{SiO}_{2} \\
\mathrm{CaO}-\mathrm{Fe}_{2} \mathrm{O}_{3}-\mathrm{Al}_{2} \mathrm{O}_{3}-\mathrm{SiO}_{2}
\end{gathered}
$$

The composition of $\mathrm{CaO}$ glass beads is in some ways close to Roman glasses reported in previous papers. In terms of its lead content, the lead glass bead from Massana cave could be similar to Islamic lead glasses (Smith, 1969). In terms of $\mathrm{MgO}$ and $\mathrm{K}_{2} 0$, the Massana grey and Cales Coves beads would be Roman or early Islamic glasses (Smith, 1969). Nevertheless, more research is now in progress to elucidate aspects not yet clear in the investigation of these beads: the archaeological context of the beads reported by the excavator is earlier than the abovementioned similarities would indicate.

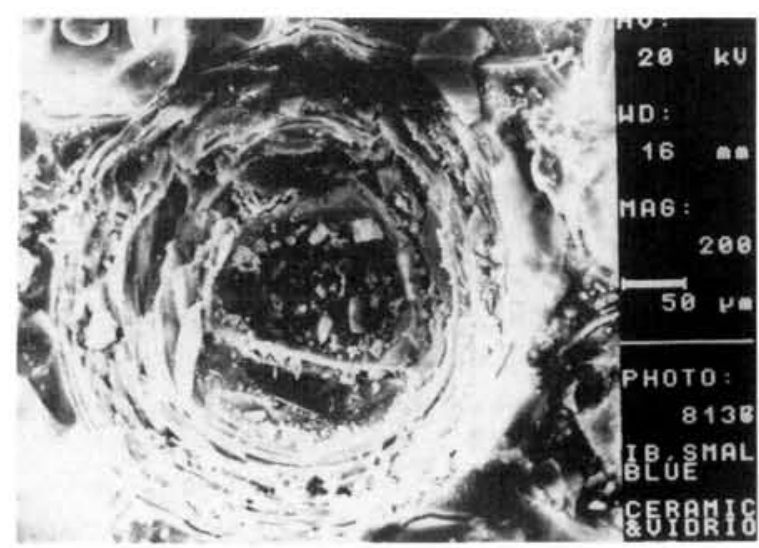

Plate III. SEM micrograph of an ancient glass bead, blue colour, from Cales Coves, Menorca, burials.

\section{AKNOWLEDGEMENTS}

Many thanks are due to P. Veny for making available the ancient glass samples for this study, and thanks also to M. Romero for his kind cooperation and A. Gilman for his review of the English.

\section{BIBLIOGRAPHY}

Amorós, L. (1974): «La cueva sepulcral preromana de Son Maimó en el término municipal de Petra, Mallorca». VI Symposium de Prehistoria Peninsular: 137-170. Barcelona.

ENSEÑAT, C. (1981): «Las cuevas sepulcrales mallorquinas de la Edad del Hierro". Revista de Estudios Arqueológicos, 118: 26-64. Madrid.

Frontán, F. L. (1991): «Materiales de la cueva de Son Bauzá (Mallorca)". Trabajos de Prehistoria, 48: 103-134.

McCARThy, J. J. and SChamber, F. H. (1979): "LeastSquares Fit witll digital filter: A status report National Bureau of Standars». Special Public. 604. Proceedings of Workshop on EDX, april, 273-296. Washington D. C.

RinCón, J. M. ${ }^{a}$ (1984): «Análisis y microestructura de vidrios romanos de Mérida y Segóbriga”. Revista de Arqueología, 43: 34-39.

SMITH, R. W. (1969): «The Analytical Study of Glass in Archaelogical Science». Economic Culture Foundation. Londres: 614-623.

VENY, C. (1982): «La necrópolis protohistórica de Cales Coves, Menorca”. Trabajosde Prehistoria:55-241. Madrid.

Waldren, W. H. (1981): Balearic Prehistoric Ecology and Culture: the excavation and study of certain caves, rock shelters and settlements. B.A.R. Intern. ser., 140. Oxford. 